\title{
PLURALISME AGAMA DAN KERUKUNAN HIDUP BERAGAMA
}

\author{
Oleh: \\ Umi Hanik
}

\section{Abstrak}

Artikel ini membahas tentang konsep pluralisme agama dan kaitannya dengan kehidupan masyarakat beragama yang rukun. Sebagaimana karakteristik masyarakat Indonesia yang sangat majemuk (plural society), yang jika tidak ada sistem masyarakat yang mengikat satu sama lain akan menjadi sumber konfil, baik vertical maupun horizontal.

Perlu ditegaskan bahwa pluralisme yang dimaksud disini harus diartikan dan difahami dalam kerangka Pluralisme menurut ukuran ke Indonesiaan, bukan menurut ukuran dan dalam konteks masyarakat kolonial. Sebagaimana dikatakan Nasikun, bahwa masyarakat Indonesia merupakan masyarakat yang bersifat Plural yang berbeda.

Pluralisme yang dimiliki oleh bangsa Indonesia tersebut secara positif telah mampu memperkaya khasanah kultural bangsa Indonesia yang menjadi kebanggaan nasional dalam kerangka "Nasionalisme Bangsa" Namun disilain , Pluralisme sebagaimana sering diungkapkan oleh para ahli menjadi potensi sosial yang meredam berbagai sumber konflik. Karena adanya potensi sosial ke arah disintegrasi, sangatlah wajar apabila pluralisme menjadi persoalan pelik dalam integrasi nasional di Indonesia.

Kata Kunci ; Pluralisme Agama, Kerukunan Hidup Beragama

* STAIN Kediri

Volume 26 Nomor 2 September 2015 


\section{Pendahuluan}

Kehidupan beragama di Indonesia yang memiliki kemajemukan suku, ras, agama, dan budaya, menjadi lahan yang subur bagi tumbuh kembangnya banyak agama, paling tidak ada lima agama yang diakui secara resmi, yaitu Islam, Kristen, Katholik, Hindu dan Budha. Dengan tidak selalu jauh membicarakan masalah perkembangan agama tersebut, yang penting diungkapkan disini adalah agama-agama tersebut yang sedemikian jauh telah membantu masyarakat yang majemuk di Indonesia, ternyata dalam kehidupan sosio-kultural memperlihatkan suatu keunikan tersendiri, sehingga anatara agama-agama yang ada terjadi akulturasi kemudian memperkaya tradisi dari masing-masing agama. Seperti halnya agama Islam, masuk ke Indonesia tidak melakukan konfrontasi terhadap tradisi lokal yang telah ada yang di bawa oleh agama Hindu dan Budha. Namun seperti yang telah dikatakan oleh (Taufik Abdullah, 1989:59) adalah melakukan peminjaman budaya karena menurut Guillemin (1983:6), kesatuan faham antara adat dan konsepsi-konsepsi yang dikehendaki oleh citacita religius tidak pernah mampu seluruhnya merealisasi diri. Disini prinsip-prinsip suatu agama di dunia yang tidak dapat diubah, universal dan holistik. Menghadapi atau dihadapi oleh proses pempribumian dimana Islam mengadaptasi dirinya sendiri, mengaktualisasikan diri dan menjadi relevan dan bermakna bagi penduduk lokal.

Dari gambaran sejarah yang terungkap diatas menunjukkkan bahwa Pluralisme agama ternyata pernah merealisasikan diri dalam bentuk yang harmonis bukan konfrontasi atau disintegrasi. Namun tidak selamanya demikian, sebab dalam suatu peristiwa yang berbeda Pluralisme agama juga melahirkan bentuk konfrontasi yang mengakibatkan Pluralitas agama masih membentuk jarak sosial yang melebar dari pemeluk agama yang berbeda. 
Upaya untuk mewujudkan kerukunan dan ketentraman hidup bagi umat beragama di Indonesia merupakan suatu hal yang mutlak diperlukan, dalam kerangka menciptakan kondisi kondusif sebagai cita-cita dan harapan bagi masa depan bangsa dan negara Republik Indonesia.

\section{Pluralisme Agama dan erukunan Hidup Beragama}

Konsep masyarakat majemuk (plural society) dalam konteks masyarakat Indonesia seperti yang dikemukakan oleh Furnivall (Nasikun, 1995 : 29), sebagai gambaran masyarakat yang terdiri atas dua atau lebih elemen yang hidup sendirisendiri tanpa ada pembaruan satu sama lain dalam suatu tatanan politik. Dari konsep yang dikemukakan di atas menunjukkan bahwa masyarakat Indonesia dengan kemajemukan yang dimiliki telah menjadi wacana kulturalnya bukan hanya pada masa Hindia-Belanda yang justru lebih banyak mengandung muatan ekonomi dan politik, tetapi jauh sebelumnya kemajemukan telah menjadi bagian kehidupan masyarakat Indonesia sejak awal kehadirannya, sehingga memperlihatkan ciri yang unik secara horizontal dan vertikal, sebagaiamana dikatakan oleh Nasikun, struktur masyarakat Indonesia ditandai oleh dua cirinya yang bersifat unik. Secara horizontal ditandai oleh kenyataan adanya kesatuan social berdasarkan perbedaanperbedaan suku bangsa, agama, adat dan kedaerahan. Secara vertical struktural masyarakat Indonesia ditandai oleh adanya perbedaan antara lapisan atas dan lapisan bawah yang cukup tajam. Perbedaan - perbedaan suku bangsa , agama, adat istiadat dan kedaerahan, seringkali disebut sebagai ciri khas masyarakat Indonesia yang bersifat majemuk.

Menurut Alwi Shihab (1997:41), pluralisme agama dipahami sebagai : (1) Pluralisme tidak semata-mata menunjuk pada kenyataan tentang adanya kemajemukan. Namun yang dimaksud adalah keterlibatan aktif terhadap kenyataan 
kemajemukan tersebut. Atau dengan kata lain pluralisme agama adalah bahwa tiap pemeluk agama dituntut bukan saja mengakui keberadaan dan hak agama lain, tetapi juga terlibat dalam memahami perbedaan dan persamaan guna terciptanya kerukunan dan kebhinekaan; (2) Pluralisme harus dibedakan dengan kosmopolitanisme menunjuk kepada suatu realita dimana aneka ragam agama, ras dan bangsa hidup berdampingan di suatu lokasi: (3) Konsep Pluralisme tidak dapat disamakan dengan relativisme. Tidak dapat dipungkiri bahwa dalam paham pluralisme terdapat unsure relativisme, yaitu unsur tidak mengklaim pemilikan tunggal (monopoli) atas semua kebenaran, apalagi memaksakan kebenaran tersebut pada pihak lain.

Tentang pluralisme agama-agama dalam konteks Islam dan universalitas nilai-nilai agama samawi serta agama-agama yang berasal dari budaya, disebutkan "Addinnu wākhidun wasyaariatu muhtalifatun" bahwa agama itu satu sedangkan caranya bisa berbeda-beda. Keberadaan agama-agama di Indonesia secara empiris khususnya yang terjadi dalam masyarakat Jawa, pluralitas agama yang terjadi tidak memperlihatkan perbedaan keagamaan secara formal tetapi lebih menonjolkan penjiwaan, sikap dan perilaku sehari-hari yang terintegrasi dengan budaya masyarakat setempat.

Pluralisme agama masih menjadi bagian dari kehidupan keberagaman masyarakat di Indonesia dan tidak akan hilang sampai masa-masa yang akan datang. Oleh karena itu, pluralisme adalah bagian dari proses tradisionalisasi dan sekaligus sebagai proses modernisasi (Jacobs, 1994:29). Sebagaimana (Gertz, 1965 : 105) mengatakan, bahwa masyarakat majemuk adalah merupakan masyarakat yang terbagi dalam sub-sub sistem yang kurang lebih berdiri sendiri, dalam masing-masing sub sistem terikat ke dalam oleh ikatanikatan yang bersifat promordial. Walaupun beberapa konsep 
dasar yang dikemukakan oleh dua orang ahli diatas telah memberikan gambaran tentang masyarakat plural, maka akan lebih lengkap jika pendapat (Pierre Van Den Berghe, 1967:67 68) menjadi salah satu referensi yang patut diketengahkan, bahwa masyarakat plural memiliki beberapa karakteristi ksebagai sifat-sifat, yaitu : (1) Terjadinya segmentasi ke dalam bentuk-bentuk kelompok yang sering kali memilki sub kebudayaan yang berbeda satu sama yang lainnya; (2) Memiliki struktur sosial yang terbagi-bagi kedalam lembaga yang bersifat non komplomenter; (3) Kurang mengembangkan konsensus diantara anggotanya terhadap nilai-nilai yang bersifat dasar; (4) Secara relatif sering mengalami konflik-konflik kelompok yang satu dengan kelompok yang lain (5) Secara relatif integrasi sosial tumbuh diatas paksaan dan ketergantungan di dalam bidang ekonomi; (6) Dominasi politik oleh suatu kelompok terhadap kelompok lainnya.

Perlu ditegaskan bahwa pluralisme yang dimaksud disini harus diartikan dan difahami dalam kerangka Pluralisme menurut ukuran ke Indonesiaan, bukan menurut ukuran dan dalam konteks masyarakat kolonial. Sebagaimana dikatakan (Nasikun, 1995:34), masyarakat Indonesia merupakan masyarakat yang bersifat Plural yang berbeda.

Pluralisme yang dimiliki oleh bangsa Indonesia tersebut secara positif telah mampu memperkaya khasanah kultural bangsa Indonesia yang menjadi kebanggaan nasional dalam kerangka "Nasionalisme Bangsa" Namun disilain , Pluralisme sebagaimana sering diungkapkan oleh para ahli menjadi potensi sosial yang meredam berbagai sumber konflik. Karena adanya potensi sosial ke arah disintegrasi, sangatlah wajar apabila pluralisme menjadi persoalan pelik dalam integrasi nasional di Indonesia (Kontjaraningrat, 1984:345 - 370).

Untuk kehidupan agama, Indonesia menjadi lahan yang subur bagi tumbuh kembangnya banyak agama, paling tidak ada 
lima agama yang diakui secara resmi, yaitu Islam, Kristen, Katholik, Hindu dan Budha. Dengan tidak selalu jauh membicarakan masalah perkembangan agama tersebut, yang penting diungkapkan disini adalah agama-agama tersebut yang sedemikian jauh telah membantu masyarakat yang majemuk di Indonesia, ternyata dalam kehidupan sosio-kultural memperlihatkan suatu keunikan tersendiri, sehingga anatara agama-agama yang ada terjadi akulturasi kemudian memperkaya tradisi dari masing-masing agama. Seperti halnya agama Islam, masuk ke Indonesia tidak melakukan konfrontasi terhadap tradisi lokal yang telah ada yang di bawa oleh agama Hindu dan Budha. Namun seperti yang telah dikatakan oleh (Taufik Abdullah, 1989:59) adalah melakukan peminjaman budaya karena menurut Guillemin (1983:6), kesatuan faham antara adat dan konsepsi-konsepsi yang dikehendaki oleh citacita religius tidak pernah mampu seluruhnya merealisasi diri. Disini prinsip-prinsip suatu agama di dunia yang tidak dapat diubah, universal dan holistik. Menghadapi atau dihadapi oleh proses pempribumian dimana Islam mengadaptasi dirinya sendiri, mengaktualisasikan diri dan menjadi relevan dan bermakna bagi penduduk lokal.

Dari gambaran sejarah yang terungkap diatas menunjukkkan bahwa Pluralisme agama ternyata pernah merealisasikan diri dalam bentuk yang harmonis bukan konfrontasi atau disintegrasi. Namun tidak selamanya demikian, sebab dalam suatu peristiwa yang berbeda Pluralisme agama juga melahirkan bentuk konfrontasi yang mengakibatkan Pluralitas agama masih membentuk jarak sosial yang melebar dari pemeluk agama yang berbeda.

Upaya untuk mewujudkan kerukunan dan ketentraman hidup bagi umat beragama di Indonesia merupakan suatu hal yang mutlak diperlukan, dalam kerangka menciptakan kondisi 
kondusif sebagai cita-cita dan harapan bagi masa depan bangsa dan negara Republik Indonesia.

Menurut Mukti Ali (1975:70), kerukunan hidup beragama akan dapat dicapai bila dilakukan melalui pendekatan antara lain memahami eksistensi agama lain. Untuk mencapai pemahaman yang komprehensip terhadap agama lain, lapang dada merupakan persyaratan yang harus dipenuhi oleh penganut agama lain, karena dalam kehidupan dan kemajuan masyarakat plural, apabila ia diwujudkan dalam bentuk sikap - sikap tersebut.

Dalam upaya memahami agamanya sendiri menurut Mukti Ali dilakukan secara parsial dan integral, secara integral diperlukan syarat-syarat : intelektual, yaitu upaya untuk dapat memahami agama atau fenomena agama secara menyeluruh, informasi yang cukup, perlu dimiliki. Tidak ada harapan untuk memahami agama tanpa adanya informasi itu. Terhadap masalah ini, sangat ideal jika orang ingin mempelajari suatu agama lain dengan memahami bahasa agama itu sendiri. Akan tetapi memahami bahasa agama tidak menjamin untuk bisa memahami bahasa agama dengan baik, artinya dapat memahami suatu agama, tidaklah harus membaca kitab sucinya dan ajaran ajarannya dalam bahasa aslinya (Ali, 1990:48); kondisi emosional yang cukup, yaitu memahami agama yang bukan agamanya sendiri, yang diperlukan bukan sikap masa bodoh sebagaimana yang dilakukan oleh kaum positifis, tetapi diperlukan adanya feeling, perhatian dan partisipasi. Ini bukanlah merupakan persetujuan terhadap pendapat yang merata, bahwa agama semacam ini merupakan masalah emosional belaka seperti pendapatnya Sehleirmacher dan Otto. Tetapi agama mencakup manusia dalam totalitasnya yang melibatkan intelek, emosi dan kemauan. Kemauan yaitu kemauan orang yang ingin mengetahui agama orang lain harus ditujukan dan diarahkan kepada konstruktif. Sikap masa bodoh 
atau terlalu bergairah yang menghapuskan apa saja yang berbeda dengan pendapatnyamerupakan hal yang tidak sesuai dengan tujuan ini. Kebodohan, cinta yang tidak terkontrol dan tidak adanya arah merupakan musuh - musuh bagi pikiran yang berusaha untuk mengetahui agama lain. Istilah pengalaman disini digunakan dalam arti yang sangat luas yang tentunya berbeda dengan konsep pengalaman yang sempit. Orang yang memiliki pengalaman yang luas dengan watak - watak manusia yang memiliki kualifikasi yang lebih baik akan dapat memahami agama lain, karena dengan pengalamannya menghubungkan pikiran orang lain dalam berbagai macam perbuatan, perasaan dan cara berfikir. Seorang ateis tidak dapat mengambil bagian dalam dialog, juga dalam mempelajari agama - agama lain karena pengalaman agama tidak dimiliki olehnya (Ali, 1996:114): (2) Dialog antar umat beragama bukanlah apologi dimana orang berusaha membantah agama lain dengan menuntut pertanggung jawab, yang didasari oleh saling pengertiandalam menanggulangi persoalan kehidupan bangsa yang lebih dan makin baik, baik dari segi materiil maupun spirituil (Ali, 1975:69).

\section{Kesimpulan}

Dari paparan pembahasan di atas, dapat disimpulkan bahwa untuk menjaga kerukunan kehidupan beragama di Indonesia dapat ditawarkan beberapa bentuk dialog yang mungkin dapat dilakukan dalam kehidupan yang pluralis, meliputi : (1) Dialog kehidupan. Dalam dialog ini orang dari berbagai macam agama berusaha untuk hidup secara terbuka dan bertetangga baik bersama-sama mereka bergembira dan merasa susah terhadap masalah-masalah yang mereka hadapi, mereka berusaha untuk menyelesaikan masalah-masalah yang mereka hadapi bersama. Dialog ini terjadi dalam negeri yang penduduknya terdiri dari berbagai macam pemeluk agama dan 
hidup mereka rukun: (2) Dialog perbuatan. Dalam dialog ini orang dari berbagai macam agama bekerjasama untuk membangun dan membebaskan rakyat dari segala macam penderitaan. Dialog yang sekarang dilakukan di Indonesia barangkali merupakan dialog perbuatan, yaitu umat beragama tanpa kecuali berusaha membangun negara kita dan menghadapi ancaman-ancaman yang mungkin mengancam negeri kita secara bersama: (3) Dialog Teologis, dimaksudkan bahwa dalam dalam dialog ini ahli agama berusaha untuk memahami ajaran-ajaran agamanya sendiri dan berusaha menghargai nilai-nilai spiritual dan penganut agama lain. Kemungkinan dari beberapa dialog yang dilaksanakan, dapat dikatakan bahwa kita berada dalam lingkaran tukar-menukar pengertian tentang agama. Kita berusaha memahami agama kita sendiri dan bersama-sama dengan itu berusaha untuk menghargai nilai-nilai yang dijunjung tinggi oleh agama-agama lain: (4) Dialog pengalaman agamis. Dilakukan melalui upaya orang yang berakar pada keyakinan dan tradisi agamanya sendiri mengambil bagian dari kekayaankekayaan rohani agama lain. Contoh tentang shalat dan perenungan kepercayaan dan cara sampai pada Tuhan Yang Maha Esa dan Maha Mutlak. Menurut Mukti Ali, dialog semacam ini pernah disaksikannya dilakukan oleh orang orangorang ahli mistik. Louis Massignon seorang orientalis Islamolog terkenal dari Perancis, manakala ia datang kenegeri Islam, maka seringkali ia menyediakan waktu untuk menziarahi kuburan orang-orang Islam yang dianggap wali. Dialog semacam ini tidak dapat dilakukan oleh umumnya orang beragama, tetapi bisa dilakukan oleh orang beragama dalam tingkatan tertentu. Namun demikian tidak dirinci cirri-ciri orang beragama yang bisa melakukan dialog ini: (5) Dialog antar monastik. Hal ini dilakukan dalam rangka saling memaknai ajaran agama lain dan menyaksikan kehidupan orang lain dalam rangka pengalaman ajaran agama. Dengan demikian pola keberagaman yang 
kondusif dengan dialog ini adalah pola keberagaman yang esotoris. Mengingat kekayaan spiritual yang dimiliki oleh suatu agama juga dimiliki oleh agama lain. Kepercayaan-kepercayaan antara agama yang satu dengan yang lain terdapat persamaanpersamaan dan juga perbedaan-perbedaan. Maka yang harus dilihat di sini bukan perbedaannya tetapi persamaannya. Oleh karena itu membangun kehidupan ummat beragama ditinjau dari agama Islam tidak lepas dari empat hal yang kesemuanya bersumber dari tauhid, yaitu: (1) Kesatuan penciptaan (Unity of Creation): (2) Kesatuan kemanusiaan (Unity of Mankind): (3) Kesatuan petunjuk (Unity of Guidance): (4) Kesatuan Tujuan (Unity of Purpose of Life). 


\section{DAFTAR PUSTAKA}

Wahid, Abdurrahman. Muslim di Tengah Pergumulan, (Jakarta : Lappenas, 1981).

Shihab, Alwi. Islam Inklusif: Menuju Sikap Terbuka dalam Beragama (Bandung : Mizan, 1999), cet. VII.

Abdullah, M. Amin, "Etika dan Dialog Antar Agama: Perspektif Islam", dalam Jurnal Ulumul Qur'an. No. 4 Vol. IV. Th. 1993.

Andito (ed.), Atas Nama Agama: Wacana Agama dalam Dialog "Bebas" Konflik, (Bandung : Pustaka Hidayah, 1998), hlm. 259.

Yatim, Badri. Sejarah Peradaban Islam (Jakarta : RajaGrafindo Persada, 1993).

Burhanuddin Daja dan Herman Leonard Beck (red.), Ilmu Perbandingan agama di Indonesia dan Belanda, (Jakarta : INIS, 1992).

Nasution, Chadijah. Sejarah dan Perkembangan Dakwah Islam (Yogyakarta : Ideal Offset, 1978).

Barton, Greg. Gagasan Islam Liberal di Indonesia: Pemikiran Neo-Modernisme Nurcholish Madjid, Djohan Effeni, Ahmad Wahib dan Abdurrahman Wahid, pent. Nanang Tahqiq (Jakarta : Paramadina, 1999), cet. I.

Guillaume, A., The Life of Muhammad: A Translation of Ibn Ishaq's Sirat Rasul Allah, (Karachi : Oxford University Press, 1970).

Hassan, Hasan Ibrahim Sejarah dan Kebudayaan Islam, terj. Djah dan Humam (Yogyakarta : Kota Kembang, 1989). 
Huntington, Samuel P., "Benturan Antar Peradaban, Masa Depan Politik Dunia?" dalam Jurnal Ulumul Qur'an, No. 5, Vol.IV Tahun 1993.

al-Faruqi, Ismail Raji (ed.), Trialog Tiga Agama Besar: Yahudi, Kristen, Islam, alih bahasa Joko Susilo Kahhar dan Supriyanto Abdullah, Cet. I (Surabaya : Pustaka Progressif, 1994).

Hidayat, Komaruddin dan Ahmad Gaus AF (ed.), Passing Over: Melintasi Batas Agama (Jakarta : Gramedia Pustaka Utama, 1998).

Michael H. Hart, Seratus Tokoh Yang Paling Berpengaruh dalam Sejarah, terj. Mahbub Djunaedi (Jakarta : Pustaka Jaya, 1990), cet. XII.

Watt, Montgomery W., Muhammad at Medina (London : Oxford University Press, 1956).

Haekal, Muhammad Husain Sejarah Hidup Muhammad, terj. Ali Audah (Jakarta : Tintamas, 1984).

Ali, A. Mukti, "Dialog between Muslims and Christians in Indonesia and its Problems" dalam Al-Jami'ah, No. 4 Th. XI Djuli 1970.

Ali, Mursyid (ed.), Studi Agama-Agama di Perguruan Tinggi, Bingkai Sosio-Kultural Kerukunan Hidup Antar Umat Beragama di Indonesia, (Jakarta : Balitbang Depag RI, 1998/1999).

Tamara, M. Nasir dan Elza Pelda Taher (ed.), Agama dan Dialog Antar Peradaban (Jakarta : Yayasan Paramadina, 1996).

Shiddiqi, Nourouzzaman, Jeram-jeram Peradaban Muslim (Yogyakarta : Pustaka Pelajar, 1996). 
Pluralisme Agama... Oleh: Umi Hanik

Madjid, Nurcholish, "Beberapa Renungan tentang Kehidupan Keagamaan untuk Generasi Mendatang", dalam Jurnal Ulumul Qur'an, No.1 Vol.IV, Th. 1993.

Parliament of the World's Religions, Declaration Toward a Global Ethic (Chicago : t.t.).

Sjalabi, A., Sedjarah dan Kebudajaan Islam (Djakarta : Djajamurni, 1970).

Stokhof, W.A.L. (red.), Ilmu Perbandingan Agama di Indonesia (Beberapa Permasalahan), ( Jakarta : INIS, 1990), jilid VII.

Sumarthana, Th. dkk. (ed.), Dialog: Kritik dan Identitas Agama.

Umar Hasyim, Toleransi dan Kemerdekaan Beragama dalam Islam sebagai Dasar Menuju Dialog dan Kerukunan Antar Agama (Surabaya : PT. Bina Ilmu, t.t.). 